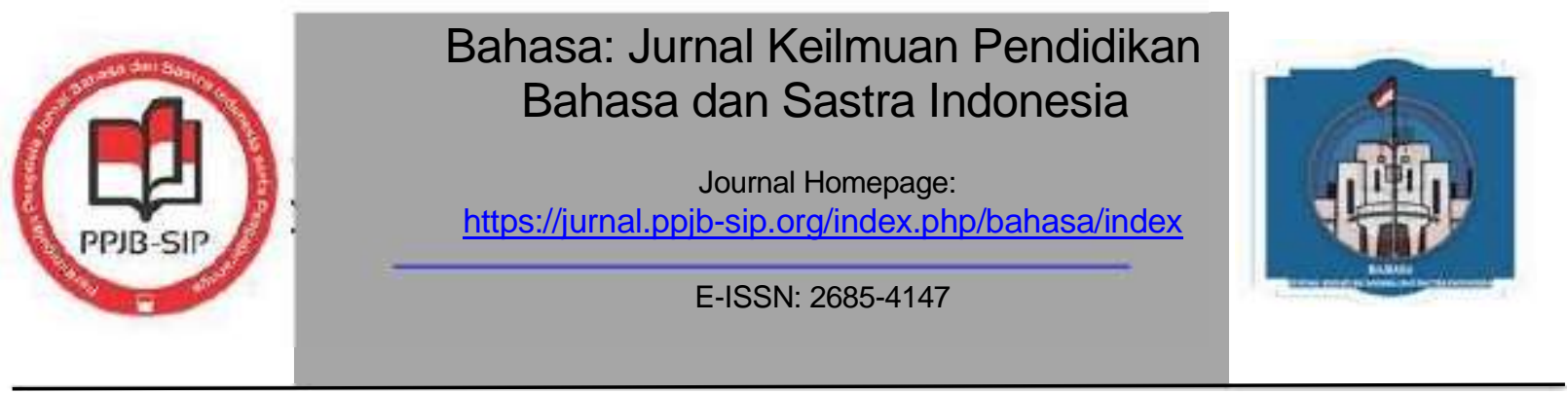

\title{
DAILY COMMUNICATION PATTERNS OF SOCIAL INTERACTION IN BATAK TOBA LANGUAGE
}

\section{POLA KOMUNIKASI SEHARI-HARI DARI INTERAKSI SOSIAL DALAM BAHASA BATAK TOBA}

\author{
Theresia Friska Damayanti Sitompul ${ }^{1}$, Indra Perdana $^{2}$, Misrita $^{3}$ \\ ${ }_{1,2,3}$ Universitas Palangkaraya \\ ${ }^{1}$ reredamayanti843@gmail.com, ${ }^{2}$ indraperdana86@gmail.com, ${ }^{3}$ ritaqal@yahoo.com
}

\begin{abstract}
This research deals with the investigation of daily communication patterns of social interaction in batak toba language. The major issues in this research were the application of daily communication patterns in aspects of social interaction where the patterns were found. Besides, this research also found the way daily communication patterns in social interaction in batak toba language are expressed. The results show that the patterns in social interaction in batak toba language are found in many aspects, they are: (1) greetings, (2) self-introduction, (3) offer, (4) giving, (5) apologizing, (6) permissions, (7) invitations, (8) reply, (9) requests, (10) regrets, and (11) leave taking. As far as the research had been done, the way the patterns in batak toba language are expressed by using terms of kinship such as amang, inang, tulang, nantulang, amang boru, namboru, ito, lae, hela, parumaen, amang bao, inang bao, bere, paraman, appara, etc. Sociolinguistically, there is not any fixed patterns for each of the routines above because they depend on some social factors, such as, terms of kinship, age, gender, and familiarity.
\end{abstract}

Key words: sociolinguistics, communication patterns, social interaction

\begin{abstract}
Penelitian ini membahas tentang investigasi pola komunikasi interaksi sosial sehari-hari dalam bahasa batak toba. Isu utama dalam penelitian ini adalah penerapan pola komunikasi sehari-hari dalam aspek interaksi sosial dimana pola tersebut ditemukan. Selain itu, penelitian ini juga menemukan cara pengungkapan pola komunikasi sehari-hari dalam interaksi sosial dalam bahasa batak toba. Hasil penelitian menunjukkan bahwa pola interaksi sosial dalam bahasa batak toba ditemukan dalam banyak aspek, yaitu: (1) salam, (2) perkenalan diri, (3) menawarkan, (4) memberi, (5) meminta maaf, ( 6) izin, (7) undangan, (8) balasan, (9) permintaan, (10) penyesalan, dan (11) pengambilan cuti. Sejauh penelitian yang telah dilakukan, cara pola dalam bahasa batak toba diungkapkan dengan menggunakan istilah kekerabatan seperti amang, inang, tulang, nantulang, amang boru, namboru, ito, lae, hela, parumaen, amang bao, inang bao, bere, paraman, appara, dll. Secara sosiolinguistik, tidak ada pola yang tetap untuk setiap rutinitas di atas karena bergantung pada beberapa faktor sosial, seperti, istilah kekerabatan, usia, jenis kelamin, dan keakraban.
\end{abstract}

Kata kunci: sosiolinguistik, pola komunikasi, interaksi social 


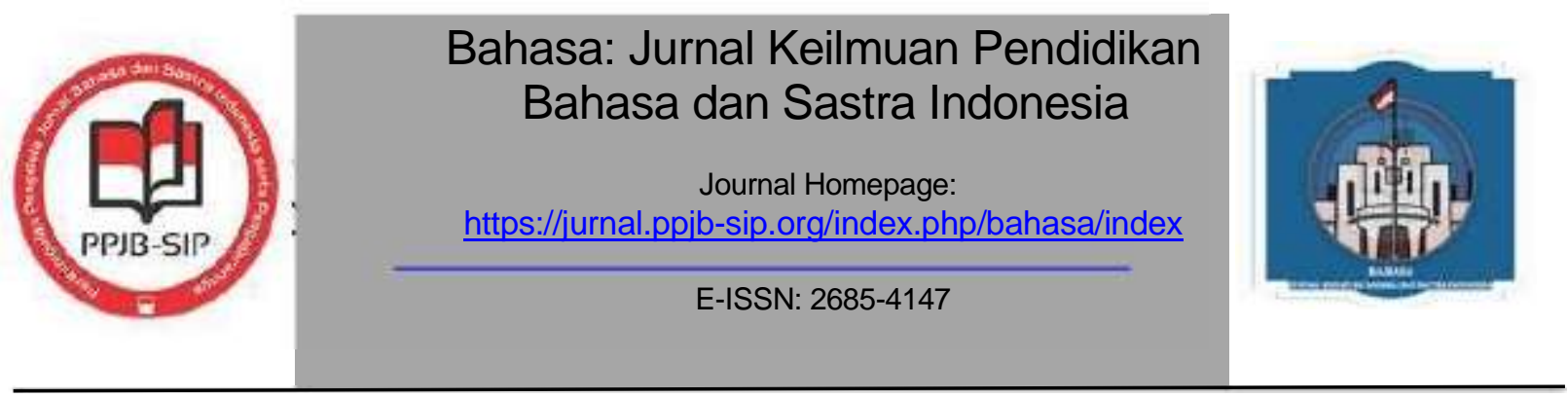

\section{INTRODUCTION}

People use language to communicate with others. Therefore, the role of language is very important in our life in doing our social activities. The use of language is often determined by norms in the society where it is used. According to Fairclough (2001:9) conversation is systematically structured, and that there is evidence of the orientation of participants to these structures in the way in which they design their own conversational turns and react to those of others." Conversation consists of two or more participants taking turns and only one participants speaking at any time.

In other words, the norms in a society rule the speakers to select one of the communication ways in order to convey their intention (Gumperz and Hymes, 2006: 50). There must be norms which may vary sub-group and social setting (Wardhaugh, 2014). In other words, every sub-group or tribe has its own norms in communication. The speakers do not speak as they like. For example, in Batak Toba language the way that speakers communicate with older people is different from the younger ones. The way that they do to communication depends on their kinship. Therefore, in Batak Toba language the sets of social norms still exist to propose the terms of kinships. In Batak Toba language, someone can be considered as polite or impolite from the way that he speaks.

The objectives of this research are to find out: (1) the aspects of social interaction where sociolinguistic routines are found and (2) the way sociolinguistic routines in social interaction in Batak Toba language are expressed.

\section{METHODS}

The study was done by using qualitative design. It is a kind of research to explore Batak Toba language phenomena naturally on the topic under discussion. The data of this research were collected from two sources, they are: (1) documentary study, the writer looked up data about sociolinguistic routines in social interaction in Batak Toba language from written conversation forms in Batak Toba language. (2) observation, the writer directly observed the participants in the field as the object of this research. Therefore, the data collected through recording are based on the natural utterances produced by the participants.

\section{RESULTS AND DISCUSSIONS}

This subchapter discusses findings and discussions of the research dealing with sociolinguistic routines in social interaction in Batak Toba language.

\section{a. Language and Social Interaction}

People use language to cooperate and to interact to person in society. We talk to our friends, our families and our associates by using language. Without language people can, not express their opinions, ideas, and their minds. The existence of language cannot be separated from the society. This phenomenon is studied in Sociolinguistics. According to Yule (2010:254), sociolinguistics is a part of sociolinguistics study which focuses on language which is dealing with social and cultural phenomenon in one society. It usually explores the 


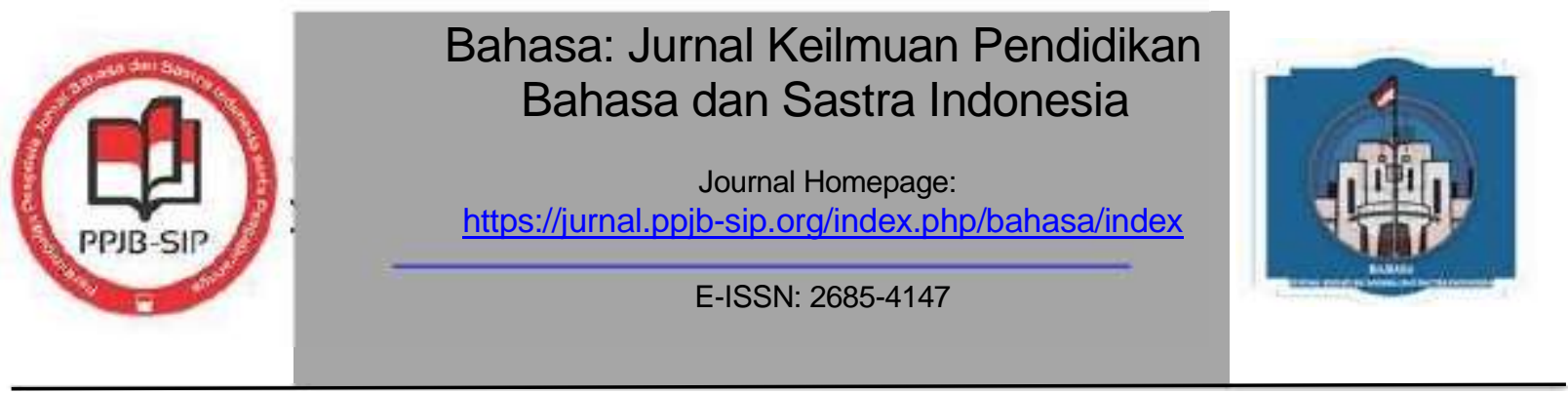

field of language, society, and things which are related to social sciences, especially psychology, anthropology, and sociology. The idea proposed by Yule is also in line with Trudgill. He states that the study of sociolinguistics is related to cultural phenomenon so that it can affect the way people speak or talk since it is determined by the social context, (Trudgill, 2000: 32). In accordance with those two linguists, Holmes (2013: 01), people who study linguistics will probably concern on describing people's different ways of speaking in different social contexts.

Moreover, Holmes argues that sociolinguists also try to investigate the use of language to convey messages. As language functions to convey messages, there must be social interactions between the members of community. Those social interactions can indicate the relationship of the people who are involved. Thus, sociolinguistics is essential in explaining the interaction between the members of the society.

\section{b. Language variation}

Everyone speaks at least one language, and probably most people in the world speak more than one. Even Americans, most of whom speak only English, usually know more than one dialect. Certainly no one talks exactly the same way at all times. The language variation exists because of the use of single language which is different within a single community, such as men do not speak like women, and older people do not speak like younger people. According to Maharani (2019), variety of language is a set of linguistics item with similar social distribution. Language variation as any speech pattern that is sufficiently homogeneous to be analysed by available techniques of synchronic description and which has a sufficiently large repertory of elements and their arrangement or process with broad enough semantic scope to function in all normal context of communication.

\section{c. Language style}

Language is not simply a means of communicating information about a subject, but it is also a very important means of establishing and maintaining relationships with other people. According to Llamas (2007:95) "language style is dimension of language where individual speakers have a choice". People do not always speak in consistently the same way. In fact people shifting the way we speak constantly as we move from one situation to another. Style is the linguistic idiosyncrasy of an individual. Style is personal. Style in social roles includes expected behavior associated with a particular status. It is more flexible than status and varies also according to the speech situation. Incompatibility of requirements imposed by roles upon individuals may result in a role strain and role conflict.

Maharani (2019) said that language style is a way to express the idea with special language show the writer's soul, spirit and concert (the use of vocabulary). Good language must have 4 elements, thus are: honestly, respect, good manners, and the last is interest. In the other opinion is Eckert (2002:1) "language style is pivotal construct in the study of sociolinguistics variation". Language style is the locus of the individual's internalization of broader social of distribution variation. The broad conception on style as a social of 


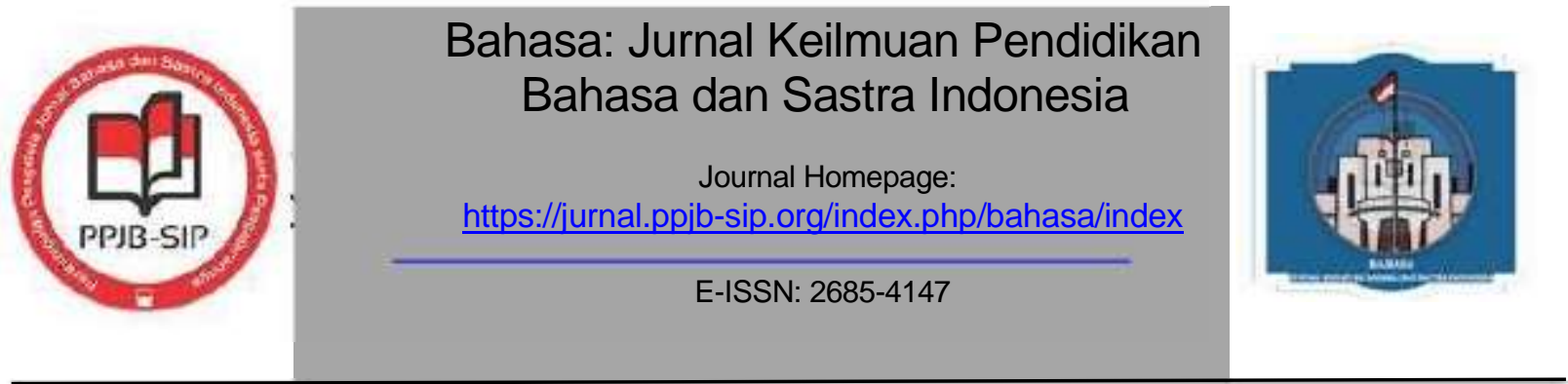

distinctiveness has some precedents is sociological work. Using style in the same loose fashion, however, hardly solves anything, and goes against the usage of style by most people in relation to individual texts or individual speakers. Another thing that complicates the study of dialect is the fact that speakers can adopt different styles of speaking depending on the circumstances speakers can speak very formally or informally.

From those statements above, the language style means different way in communicating with other. It is clear that language is a rule-based system of signs. Saying that language is rule-based usually makes people think of other kinds of situations where rules are enforced by a particular authority. We usually evaluate a person's education, socio-economic level, background, honesty, friendliness, and numerous other qualities by how that person speaks.

\section{d. Function of Language style}

Hidayat, (2011) defines the functions of language stye as follows:

a. To increase the Audience's taste.

Using the stylish language can raise .the audience's thought toward what is being said the actor, in this case, the actor it will increase the public's opinion about what has been written or said, what it means, purposes, need, and wants.

b. To persuade the reader.

The functions of language style also can make the audience sure of what the audience or speaker has stated. Generally, the writer or the speaker attracts the reader using the rhetorical language.

c. To create certain mood.

The language style that is used by the actors can influence the audiences feeling and thinking. Thus, how the actors use the language style in their advertisement will create certain mood.

\section{e. Social Interaction}

Social interaction cannot be separated from human life. It is a pattern of interaction among the society members to thread communication, not only in verbal communication but also in non-verbal communication in their daily life. The term non-verbal communication or body language as it is also commonly known, refers to the bodily movements which accompany speech and which add meaning to the interaction (Thompson: 2018).

However, social interaction is embodied in cultural rules and norms, and it is thought by the parents to younger generation indirectly. One of the simple examples of the social interaction among society members are greeting by using special expression in their own language. Other examples are hugging and shaking hands.

\section{f. Sociolinguistic Routines}

Talking about sociolinguistic routines, there is a proverb in bahasa Indonesia saying lain lubuk, lain ikannya. For this discussion, the proverb can be interpreted as different place, 


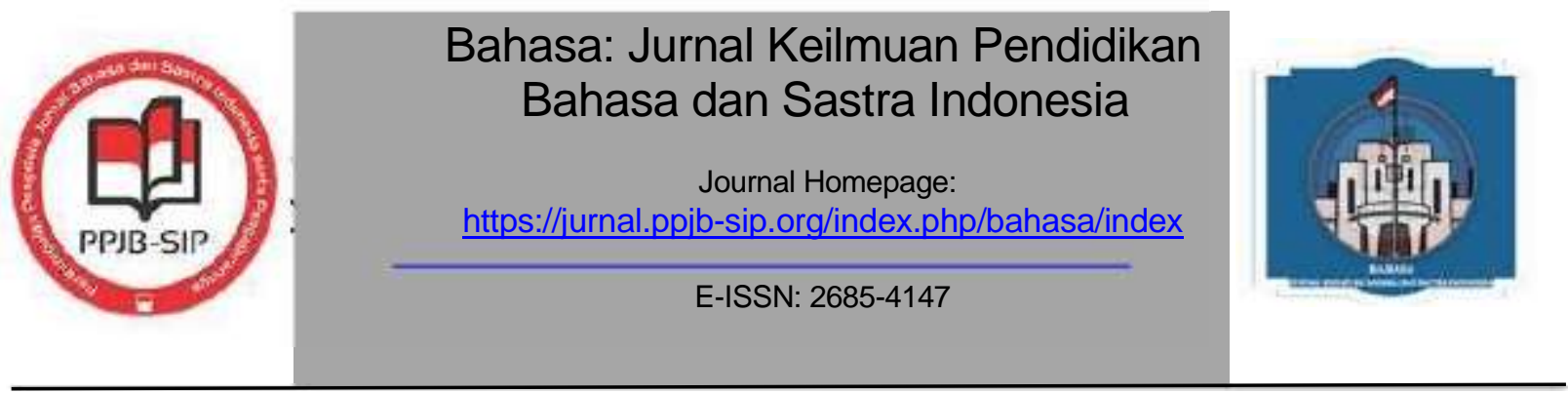

different language. That is to say, every language has their own ways to express ideas in social interaction. These kinds of expression are usually called routines.

The results show that sociolinguistic routines in social interaction in Batak Toba language are found in many aspects of communication. They are explained in the following parts.

\section{1) Greeting}

Greeting is the first word used in accosting somebody or writing to somebody for expressing respect and relationship. Every community has its own special ways of greeting. In Batak Toba community it usually occurs in social meeting, feast, accidental meeting, or when some friends or relatives are visiting their homes and their villages. Greeting is usually a token of good relationship between a speaker and listener. There are many ways to show respect to other. For instance, we have to know first the term of kinship that exists in Batak Toba.

For example:

- Horas among, nunga leleng hita dang pajumpang Horas father, it is been a long time since we've seen each other.

- Horas, boha do kabar keluarga? Anak-anak sehat do ?

Horas, how are your family? Are the children healthy?

- Horas, boha kesibukan muna sonari amang bao? Idia tinggal muna sonari?

Horas, what are you busy right now brother-in-law? Where do you live now?

Horas in Batak Toba language is a very famous word. Literally, Horas means long life. The word Horas is even used not only by Batak Toba language speakers but also by people who do not speak Batak Toba language where they meet Batak Toba people or when visitors come to Batak land 'Tano Batak'. In Batak Toba language, the word amang has more than one meaning. The word among as in Horas among means 'father in law or male adult person. We can draw the meaning from the context of their conversation, where speaker B uses the word amang bao in his reply. In other words, the brother-in-law greets his father-in-law in the conversation. In Batak Toba language, the word horas is a very frequent routine used in greeting among speakers who thread communication.

\section{2) Self-Introduction}

Besides greetings, sociolinguistic routines in Batak Toba language are also found in self introduction. Self-introduction is the expression used by somebody to introduce himself to someone else. For Batak Toba people, this kind of expression often occurs in the situation if two or more persons meet accidentally and they do not know each other.

In Batak Toba, for example, self-introduction can be done as in the following:

- Horas, goar hu Leli. Au boru Sitorus, omakku boru Manullang. Alamat nami di Jl Manjuhan. Au anak siangkangan. Hami bersaudara tolu halak, 2 boru 1 bawa.

Horas, my name is Leli. I am boru Sitorus. My mother is boru Manullang. Our address is on Jalan Manjuhan. I am the eldest child. We are three brothers, 2 girls 1 boy. 


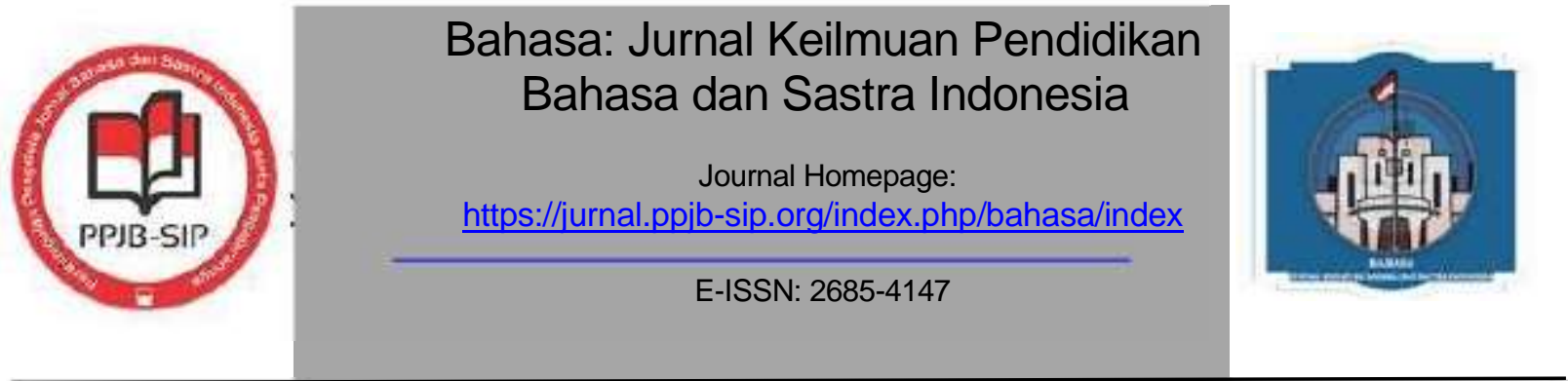

When Batak Toba people are introducing themselves, it is a custom for them to shake hands strictly and a bit longer while they are extending shorter conversation. In addition, for adult and married Batak Toba people they never introduce themselves by saying name . On the other hand, they just say their family name. Sometimes, male Batak Toba person introduce themselves by saying his eldest child with introductory phrase ama $n i$ 'the father of. For example : Ama ni Jonathan do panggoaranhu. For female married Batak Toba person, the term of kinship used is nai for example: Nai Jesika do panggoaranhu.

Further, a person who has already got grandchild or grandchildren will introduce themselves by saying introductory phrase oтри or grand father of or 'grand mother of'. The name of the grandchild added to the word ompu is taken from the name's of the eldest child of the son's side. For example: "Ompu Binsar do au" For Batak Toba people, the title ompu is considered honourable. That is why, to have nick name ompu is a waited call for persons who are already old whose children already got married.

\section{3) Offering}

The other kind of sociolinguistic routines in Batak Toba language is offering. It is the action of offering or giving something to someone else. In Batak Toba language, offering may occur in serving meals to guests.

Offering also occurs in wedding party. In this party, the parents of the newly married couple come to meet their guests when they are enjoying their meal in the party. In this occasion the parents of the newly married couple will offer their guests to enjoy the meal by saying:

- Jolo marsipanganon ma hita ate, adong do saotik na hupatupa hami.

Let's eat first, we have prepared some food for us.

- Apala aha na ringkot amang diharoro muna? Molo boi hubantu hami pe nasatolap ni gogo nami.

Is there anything that you need dad? If it is possible, let is we try to help you.

- Godang-godang allang hamu ate.

Please, eat a lot guys.

\section{4) Giving}

Giving is an act of handing something to another person without payment or exchange. In Batak Toba culture there is a term mamiringi. Mamiringi is the action of giving food to the neighbour, especially when the host has guests who bring food to their home. Some of the food will be given to the neighbour. In other occasion, when the neighbour has guests with food, the neighbour will do the same thing as well. This is a very good tradition in Batak Toba culture. The conversation can be seen as in the following:

- Jolo marsipanganon ma hita ate, adong do saotik na hupatupa hami

Let's eat first, we have prepared a little.

In Batak Toba culture usually the neighbour will accept the food if their relation runs well. However, if the neighbour rejects the food, their relation will be worse. 


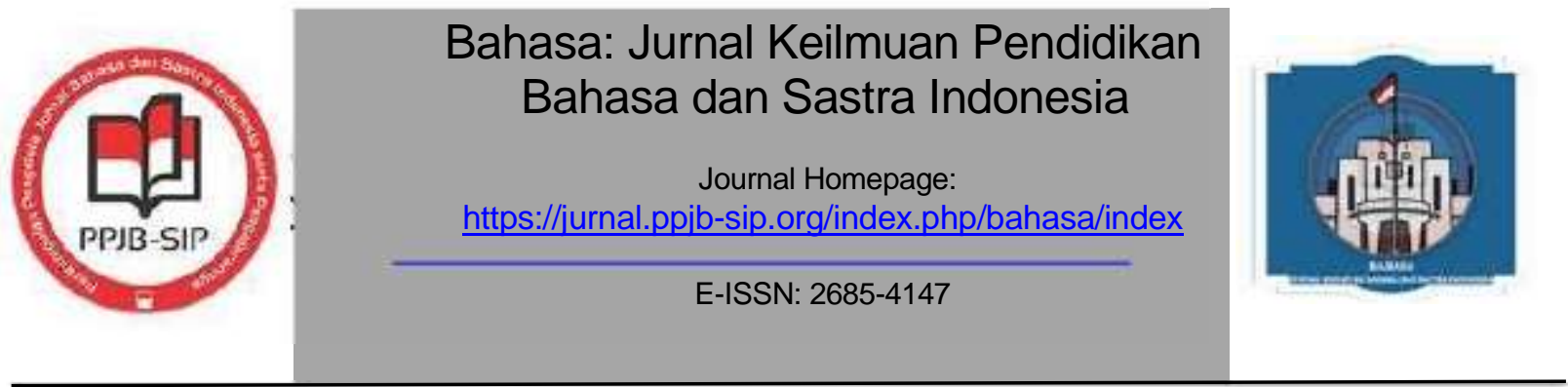

\section{5) Apologizing}

Apologizing is asking for an excuse to someone because we feel that we do something wrong. According to Lee, in Esron Ambarita (2017) there are some circumstances in which apologizing can be done, they are:

a. When someone makes a momentary mistake physically.

For example, when someone bumb or trip over somebody's feet, it is a good way to ask for pardon to the person. In Batak Toba language, this excuse can be expressed by saying:

- Mangido maaf au da, nunga mambahen hansit roham.

Sorry, I hurt your heart.

- Maaf da, terlambat ahu ro.

Sorry, I am late.

- Maaf da, dang hu tepati janjingku

Sorry, I didn't keep my promise.

- Maaf da, nunga margabus ahu. Sorry, I lied.

b. When someone damages a valuable object.

In Batak Toba language when someone damages or knocks other's valuable object, they usually say:

- Maaf da, dang sangaja mamoscahon piring muna

Sorry, I accidentally broke your plate.

c. When arriving late.

When Batak Toba people come late to an appoinment, for example, the following expression is usually mentioned.

- Nunga leleng ra hamu ate?

Have you been waiting for so long, have not you?

d. When someone fail to understand what somebody is saying.

In Batak Toba language, when someone fail to understand what somebody is saying, to ask for an exuse they usually say:

- Maaf, hurang hu antusi hata ni maksud ni ito ?

Sorry, I don't understand what do you mean?

- Santabi jolo amang boru, aha na didok hamu nangkin? Dang tangkas hu bege.

Excuse me amang boru, what did you say say ? I did not hear.

e. When causing someone to lose something or taking other possession without permission.

In Batak Toba culture, there is a tradition to take someone's possession not very valuable without permission from the owner because the owner of the thing wanted is not on the place. For instance, when a family is cooking fish, and she needs sour for the meal. It is impossible for her to go to the market because it is very far. As a short cut, 


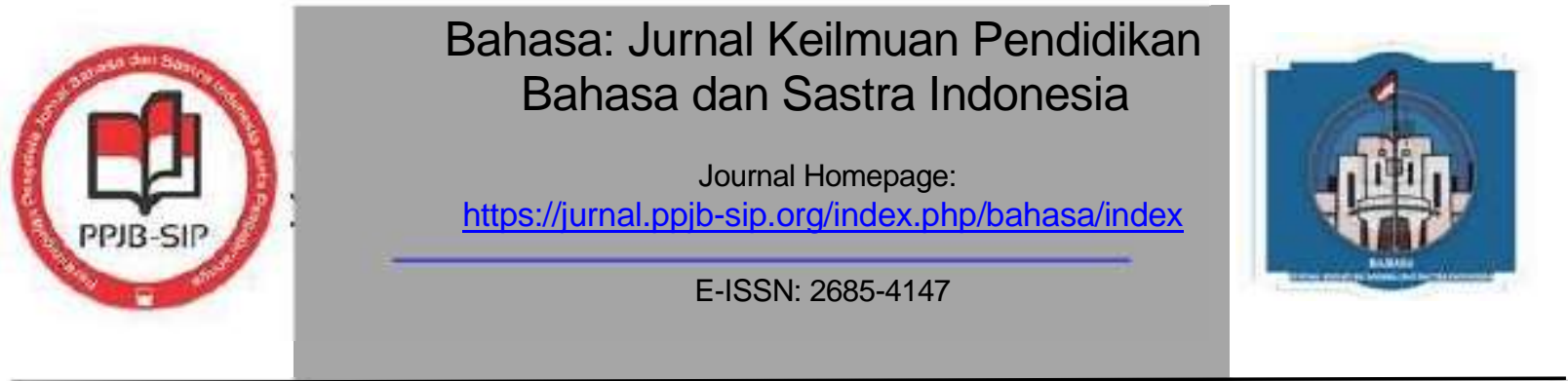

she will take her neighbour's sour from the sour tree behind her neighbour's house. As a tradition, when Batak Toba people cook fish, especially sea fish or gold fish, they usually cook it with sour. After her neighbour comes, the woman who already took the sour will express her apology to her neighbour. The following is one expression to show the apology.

- Mangido maaf da, hilang nangkin kunci ni motormu Please don't be angry. I loost your keys.

- Sotung muruk ho eda, hu buat nakkin sabiji asommu. Mangaloppa ikkan ahu. Please don't be angry with me $e d a$, I took one of your lemon. I cook fish.

\section{6) Permission}

In Batak Toba tradition, one of the circumstances in which permission is required is when someone wants to pass by other person especially older persons. This kind of permission is much done when Batak Toba people are doing partangiangan 'prayer' or making meeting or doing gathering in one house.

Usually, Batak Toba people sit in the form of cirle on mats in doing the activities above. In this situation, when one of the persons wants to go out, for example, he needs to make permission when he is passing by those persons. In Batak Toba culture, it is impolite to pass by older persons without permission. The frequent permission used by Batak Toba people in such situation is by saying:

- Santabi namboru, buat hamu jolo cuci tangan $i$

Excuse me aunty, could you help me to take the hand wash please

- Maaf ito, pagogo hamu jolo soara ni musik $i$

I am sorry brother/sister, could you help me to turn up the music please.

- Mangido tolong eda, tambahi hamu jolo indahan $i$

7) Invitation

Excuse me aunty, could you add this rice please

An invitation is a request to someone to come to a party. A very common invitation done by Batak Toba people is when there is an event mangadati 'celebrating big wedding party'. The followings are some examples of oral invitation in Batak Toba language:

- Horas ito, ro hami manggokhon, ima na naeng manjalo tuhor ni boru hita. Horas ito, we would to invite you to the wedding party of our daughter.

In Batak Toba culture, there is a tradition to invite the neighbour to enjoy the meal brought by the host's family together. The common oral invitation for this situation is:

- Beta hamu mangan tu jabutta, adong saotik sipanganon diboan ibototta.

Please come and enjoy to our house, our sister is bringing some food.

This expression is usually replied directly by saying:

- Na uli, ro pe hami.

Yes, we will come. 


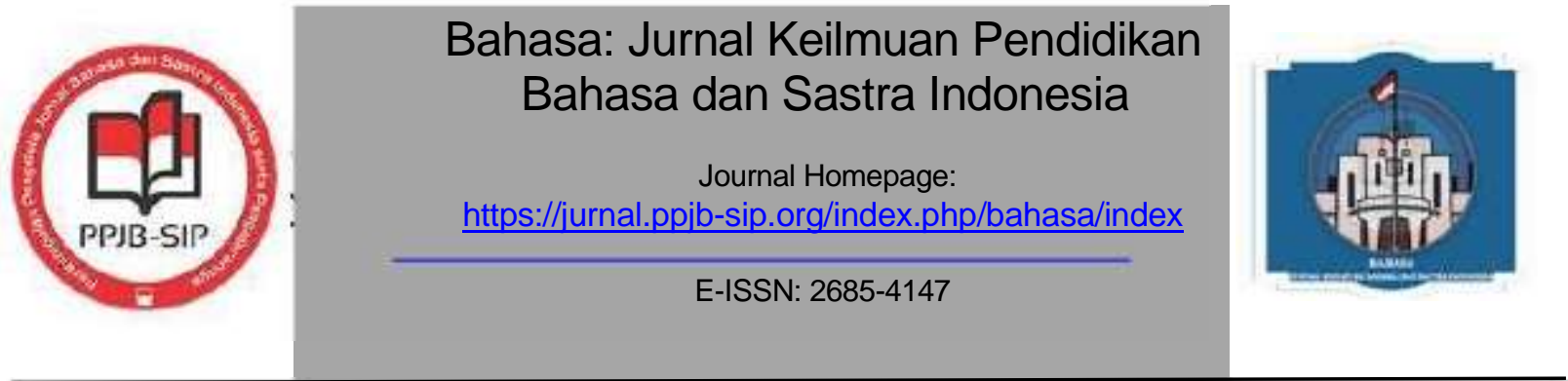

- Horas ito roma hamu anon di acara mamasuki bagas sibaganding tua Horas brother/sister, please come to our house

- Horas among ro hamu di pesta parbogason ni anak ta di ari sabtu da Horas father, please come to our parbogason party at saturday.

- Ro hamu amang di acara mamoholi pahompu muna marsogot Please come to our mamoholi party father at tomorrow.

8) Reply

Batak Toba people are very familiar with expressing deep respect to somebody else who have come to their party or who have given help. For this situation, Batak Toba people usually say:

- Mauliate godang ma di haroro muna da.

Thank you very much for your coming.

- Na uli, ro pe hami.

Yes, we will come.

\section{9) Request}

Request is done because the speaker wants someone to do a favour for him. In other words, request is an action to ask for help from somebody. According to Esron Ambarita (2017) request often includes a polite word, such as please. More over, Lee states that there are many types of utterance that can be interpreted as requests in particular contexts as in the following:

a. When a speaker requests someone to do something or get something done.

In Batak Toba language, this intention can be expressed by saying one of the following utterances:

- Santabi tulang, pa geser hamu jolo saotik.

Excuse me uncle, would you move a bit please.

In Batak Toba language, this is a very polite form of request. This kind of utterance is usually headed to someone that the speaker respects very much, or headed to someone who is not familiar with the speaker or older than the speaker. The kind of utterances of request which is usually headed to someone of the same age is as in the following.

- Geser jolo saotik bah.

Please move a bit.

The form of request headed to someone younger can be expressed as follows:

- Geserhon jolo saotik.

Move a bit. 


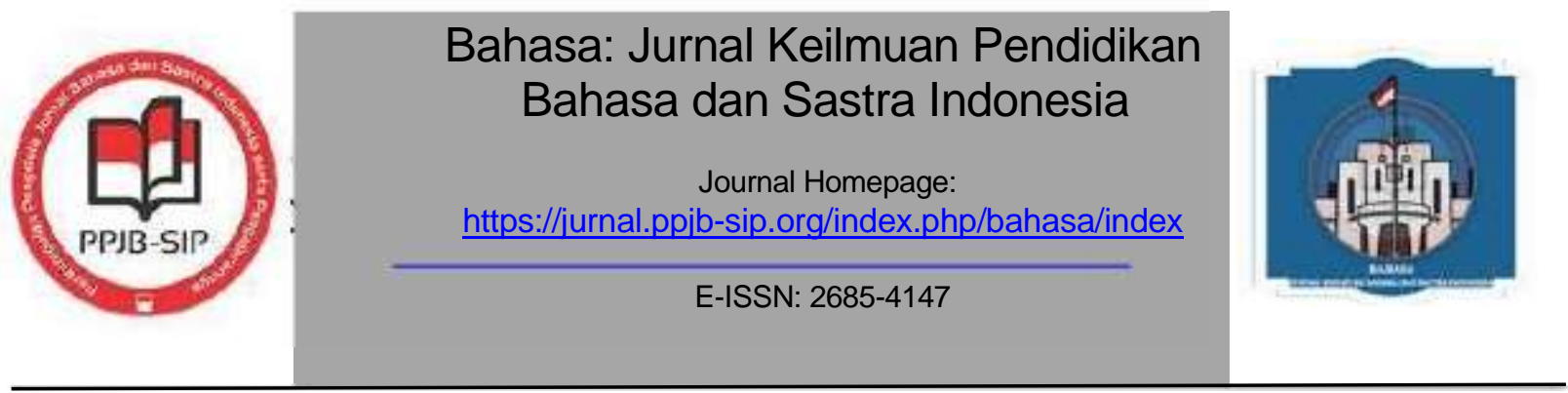

b. When a speaker needs a help. In this situation. For this context, Batak Toba people usually say:

- Marhehe na uli ma jolo hami inang. Horas ma.

Goodbye inang, we are leaving. Horas.

- Borhat ma jolo hamai ito, horas ma hita sude.

Goodbye ito, horas (long life) for all of us.

- Lao ma jolo hami eda. Sehat-sehat sude da.

\section{0) Regrets} See you later eda. I hope we are always healthy.

According to Esron Ambarita (2018) regret is defined as the feeling of sadness at the loss of something, or of annoyance or disappointment because something has or has not been done. In Batak Toba language regret can expressed by saying :

- Amangtahe, dorunna tugas on sae.

Gosh, why this task is very difficult to complete.

- Amangoi sadihari ma boi sae kredit ni jabu name on?

\section{1) Leave Taking}

Oh my God, when we can finish our home credit?

According to Esron Ambarita (2018) leave taking is a way of expressing utterance for leaving from one place. In English, for example, we say goodbye to express leave taking both for person who leaves and for person who stays. In other words, in English the expression goodbye will be replied by the same word goodbye. The other chioce to express leave taking in English is see you later, see you tomorrow, till we meet again, etc.

In bahasa Indonesia we say selamat jalan to person who leaves and selamat tinggal for person who stays. However, in Batak Toba language there is not any special expression to express leave taking. Usually the following expressions are use to express leave taking in Batak Toba language.

- Lao ma jolo hami among. Horas. See you later among. Horas (long life).

- Marhehe na uli ma jolo hami opung. Horas ma da. Goodbye opung, we are leaving. Horas (long life).

- Borhat ma jolo hami nantulang, horas-horas ma di hita sude. Goodbye nantulang. Horas-horas (long life) for us.

\section{CONCLUSION}

Based on the analysis of sociolinguistic routines in Batak Toba language above some conclusions can be drawn, they are, sociolingusitic routines in Batak Toba language are found in many aspects of social interaction, they are: (1) greetings, (2) self-introduction, (3) offer, (4) giving, (5) pologizing, (6) permissions, (7) invitations, (8) reply, (9) requests, (10) regrets, and (11) leave taking. Sociolinguistically, there is not any fixed sociolinguistic routines for each of the routines above because they depend on some social factors, such as, terms of kinship, age, gender, and familiarity. Some of the terms of kinship in Batak Toba 


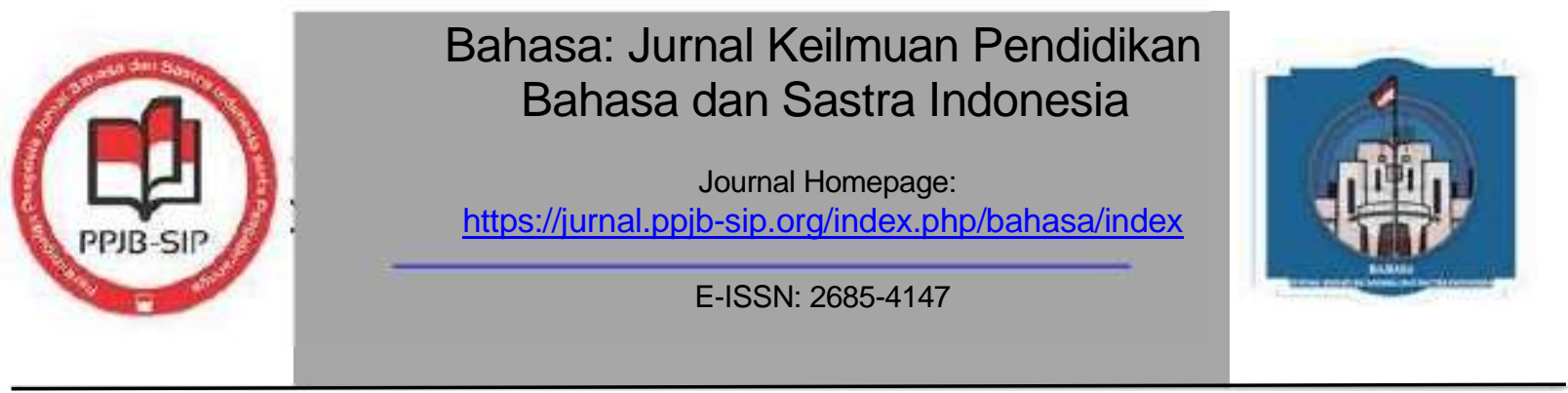

language are amang, inang, tulang, nantulang, amang boru, namboru, ito, lae, hela, parumaen, amang bao, inang bao, bere, paraman, appara, etc.

\section{ACKNOWLEDGEMENTS}

First of all, the researcher expresses gratitude for the grace and blessing from God Almighty to complete the research from this journal properly. The researcher would also like to thank all reviewers and editors who have contributed to the review process of my articles published in the Bahasa Journal. Do not forget the professional support and assistance for me as the first author in this journal, namely from the second and third authors who have very important roles in making this journal from the beginning until it can qualify for publication.

\section{REFERENCES}

Coulmas, F. (Ed.). (2011). Conversational routine: Explorations in standardized communication situations and prepatterned speech (Vol. 96). Walter de Gruyter.

Eckert, P., \& McConnell-Ginet, S. (2007). Putting communities of practice in their place. Gender \& Language, 1(1).

Fairclough, N. (2001). Critical discourse analysis as a method in social scientific research. Methods of critical discourse analysis, 5(11), 121-138.

Fairclough, N. (2001). Critical discourse analysis as a method in social scientific research. Methods of critical discourse analysis, 5(11), 121-138.

Fishman, J. A. (2019). The sociology of language: An interdisciplinary social science approach to language in society (pp. 217-404). De Gruyter Mouton.

Fishman, J. A. (2019). The sociology of language: An interdisciplinary social science approach to language in society (pp. 217-404). De Gruyter Mouton.

Ford, C. E., Thompson, S. A., \& Drake, V. (2012). Bodily-visual practices and turn continuation. Discourse processes, 49(3-4), 192-212.

Gregory, M., \& Carroll, S. (2018). Language and situation: Language varieties and their social contexts. Routledge.

Gumperz, J. J., \& Cook-Gumperz, J. (2006). Interactional sociolinguistics in the study of schooling. Studies in Interactional Sociolinguistics, 25, 50.

Hanks, P. (2013). Lexical analysis: Norms and exploitations. Mit Press.

Hidayat. (2011). Language Styles of Advertisement in Jawa Pos.

Holmes, J., \& Wilson, N. (2017). An introduction to sociolinguistics. Routledge.

Maharani, M. (2019). A SOCIOLINGUISTICS ANALYSIS OF LANGUAGE STYLE IN “WILD CHILD” MOVIE (Doctoral dissertation, Universitas Muhammadiyah Mataram).

MAHARANI, R. Z. (2019) GAYA BAHASA RETORIS DAN KIASAN DALAM LIRIK LAGU ERIC CHOU PADA ALBUM.

Esron Ambarita (2017). A Study Dictionary of Social English. New York: Pergamon Press Esron Ambarita (2018). A Study Dictionary of Social English. New York: Pergamon Press Llamas, C., \& Mullany, L. (2007). P. Stockwell. 


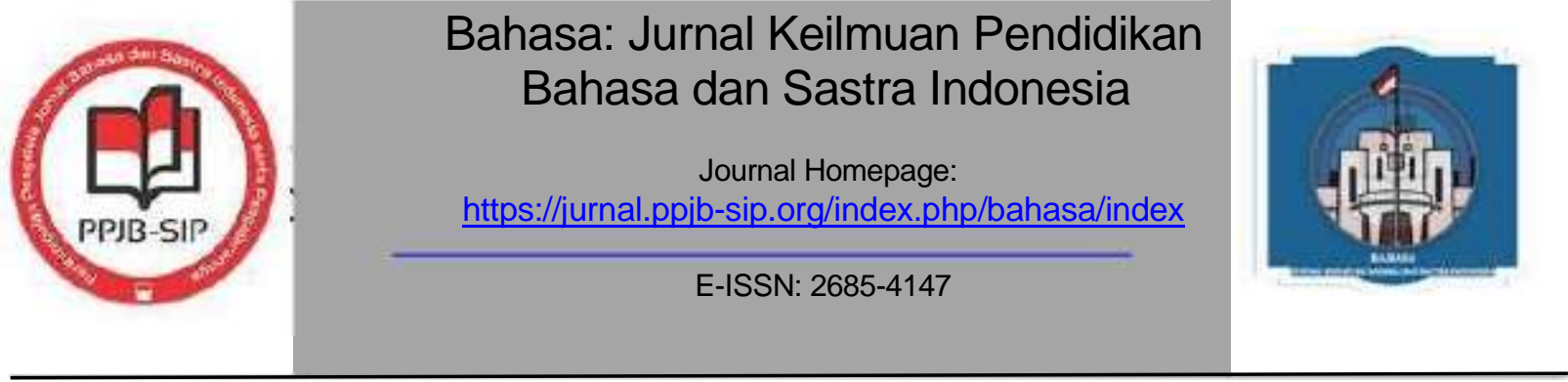

Luhmann, N. (2008). Are there still indispensable norms in our society?. Soziale Systeme, 14(1), 18-37.

O'keeffe, A., McCarthy, M., \& Carter, R. (2007). From corpus to classroom: Language use and language teaching. Cambridge University Press.

Romaine, S. (2000). Language in society: An introduction to sociolinguistics. Oxford University Press.

Shumin, K. (2002). Factors to consider: Developing adult EFL students' speaking abilities. Methodology in language teaching: An anthology of current practice, 12, 204211.

Tankard, M. E., \& Paluck, E. L. (2016). Norm perception as a vehicle for social change. Social Issues and Policy Review, 10(1), 181-211.

Thompson, N. (2018). Effective communication: A guide for the people professions. Macmillan International Higher Education.

Trudgill, P. (2000). Sociolinguistics: An introduction to language and society. Penguin UK. Wardhaugh, B. (2014). Cartels, Markets and Crime: A Normative Justification for the Criminalisation of Economic Collusion. Cambridge University Press.

Wardhaugh, R. (2010). An Introduction to Sociolinguistics (Sixth). British: Wiley Blackwell. Yule, G. (2020). The study of language. Cambridge university press. 